\title{
Significance of Ornamentation in Yoruba Traditional Architecture
}

\author{
Titilayo Anifowose and John Olatubosun
}

Department of architecture

University of Lagos Akoka, Nigeria

\begin{abstract}
Culture and tradition are vital constituents of traditional architecture. However, in the period of proliferation and modernism, traditional architecture is fast disappearing in most parts of Africa due to negligence and incredulity of its importance. Reassessment becomes necessary as traditional architecture can be a source of inspiration even in contemporary times. Through review scoped literature, this study takes a critical look at how culture affects ornaments of architecture in Nigeria with Yoruba as a case study. This paper explores significance of ornamentation in Yoruba palace architecture. This means the creative objects within the old palace ('afin') constructed when the city was formed, including the courtyards ('akodi') and other structures within the palaces. It concludes with attributes of different palace ornamentation with clear direction on key roles in the study palace cultural belief and traditions. Data was sourced from fieldwork, oral interviews and relevant literature. Purposively selected photographs of palaces 'Afin' are used in discussing the state of the architecture and sculpture objects, therefore raises the enquiry of their connotation for upcoming generations. In other words, ornamentation has a basic statement for which it was created (meaning); the mutual concern and relevance of such artifact, form, or object gives it a name, root and status in addition to identity as the material culture of the designing community. The study reveals the benefits of palace ornament to Yoruba tradition and culture and the importance of culture and history of people if the memories of their past are celebrated and their cenotaphs and antique places of pride are intact. This paper suggests that elements of palace ornaments like art and heritage architecture in Yoruba palace ornamentation have become a natural occurrence.
\end{abstract}

Keywords: Arts, Sculptures, Palace Architecture, Yoruba Values, Cultural Values.

\section{INTRODUCTION}

Art is the spin on which culture gyrates; and truly, it is the means that projects the entirety of a people's way of living. Architecture as a traditional phenomenon, is "the totality of a people's built environment and therefore includes simple as well as complex structures" $[1,2]$. Traditional Yoruba architecture cannot be studied without examining Yoruba decorative arts since both are thoroughly related in Yoruba societies. Some of the decorative arts of Yoruba palace architecture include symbols, patterns, motifs, fabrics, metal work, carving, pottery, basketry, beadwork, and wall decoration. Balogun, O. noted "Yoruba artistic intellect was strongly proclaimed in the decorative enhancement of the built environment (2). Erratic decorative patterns could be found sculpted or painted on walls and wooden doors, which ranged from rhetorical designs to elaborate intangible patterns which shown an attractive balance of form, color, and shading. Painting was conceded as an extension of architecture than an independent medium. The Yoruba palaces in Southwest Nigeria have magnificent design and structural configuration. They have several courtyards which are decisively created to house civic gatherings and festivals. An example was the old Olowo's palace in Owo, which had 27 courtyards with each courtyard having a specific function and dedicated to an idol [3]. Courtyard often has broken pottery and sun-dried mud bricks as walls finish. Doors are knottily carved with abstract design most times with images of human and animal figures, while the pillars are also carved to support the veranda's roof. For instance, the Ashanti palace (Ghana) also has several courtyards culminating around the rectangular building, the walls were decorated with a carved design made out of mud and paint. Generally, palace architecture in Yoruba are influenced by cultural factors such as occupation, family lineage, religious activities, economic activities, and the political hierarchy system in various combinations [3, 4]. Yoruba is the second largest ethnic group next to Hausa in Nigeria. For several decades, the Yorubas have displayed a culture that is unique and very captivating distinguishable to their progenitor known as Oduduwa Olofin $[5,6]$. Yoruba Palace is built to house the whole community wealth, riches, cultural artifacts, beliefs and tradition that is reflected in the ornamentation. Yorubas has close kinship ties and belief that family should live together in a compound or a house commonly referred to as Agbo Ile, that is, the family 
house $(7,8)$. Idowu, E.B. identified that the compound and courtyard architecture were the most recognized elements in the traditional Yoruba towns [9].

Most Yorùbá Palaces (ààfin) are located at the center of the city at nodal point (oríta mẹta, mẹrin) leading in from the main city gates. Palace in Yoruba land is the royal built-up region kept for no other person than the reigning monarch. Ojo, A. [10] defined palace as absolutely official abode of an Oba. It is branded by several units enclosed with courtyards. Krapf-Askari, E. defined Aafin as multiple compounds because of the various squares that described it. Generally, the front of the Yoruba palaces laid the open space for economic activities [11]. Yorùbá built more permanent palaces out of the same materials and in the same simple forms as ordinary houses, though palaces had denser walls, more ornamental designs, and bigger spaces.

Aderemi, A. et. al. mentioned that Òjó classifies Yorùbá palaces into three groups according to the rank of the reigning oba. The four pre-eminent $o b a$ according to Òjó are the Awùjalẹ of İjệbú-Òde, the Aláké of Abẹ́òkúta, the Aláàfin of Ọ̀yọ́ and the Ọ̣ọ̀ni of Ifẹ. Typologically they are, four types of palaces based on their type, size, location, site, layout, structure, and architectural style. These are Ifẹ̀, Ọyọ́, İjệbú and Ègbá [12]. In Yoruba palace architectural ornamentation, possibly the most distinctive aspect of the subject is its function as symbol. Yorùbá palace ornamentation are known for their wooden sculptures which are used as door panels, veranda posts, pillars, and stools in palace buildings. They also carve thousands of symbolic sculptures which are either used for religious or functional purposes. Aside from Yoruba sculpture in wood, they are brilliant works of metal, casters of Brass and Bronze, calabash carvings, bead works, and traditional wall adornment [12]. All these numerous creative activities are employed either along with, or in support of Yorùbá indigenous architecture, which is boundless in structure. Therefore it is clear that appreciative of the Yorùbá palaces will not be completed without study of the physical environment in which monarchs live, worship, and govern. Truly Yorùbá palace ornament architecture is an amusing scenery from which to draw a study of Yorùbá culture from Akintoye, [5].

\subsection{METHODOLOGY}

This study adopted combination of historical and qualitative analytical approaches. Conceptually, the palaces are treated as physical (culture) artifacts. Material culture is the physical evidence of a culture in the objects and architecture style they adopted. Therefore, the quest for meaning of beautifications in Yoruba Palace buildings necessitate the cultural background of Yoruba palace ornamentation in general. In addition, the oral historical method was deployed to aid in the collection of historical data on the palace buildings from the patrons and the producers (artisans) of ornaments in the study areas.

\subsection{SUMMARY OF FINDINGS AND DISCUSSIONS}

Most Yoruba palaces have developed their own collection of architectural ornaments. Some of these show up in the form of plant or floral motifs, animals and birds, symbols and heraldry, or human forms as reflected in architectural caryatids. By tradition, door carving and location of such doors signify distinct reflections of rank and prestige. Ornately carved and brightly painted doors, house-posts and sculptured mud murals were often found in the kings palaces in Yoruba towns. Yorùbá palace is magnificently built up, they are always lavishly decorated with carved posts, doors, paved floors with stones, potsherds, pebbles, seashells and cowries. In a few towns, the walls of the palaces are decorated with paintings. Samples of some prominent palaces with ornaments in Yoruba land:

\subsection{OWA'S PALACE IN ILESA}

Ilesa is a Yoruba town located in the south-western geo-political zone of Nigeria, in the Yoruba Points and at the intersection of roads from Ile-Ife, Oshogbo and Akure, which fall within Latitude $8.92^{\circ} \mathrm{N}$ Longitude $3.42^{\circ} \mathrm{E}$. Ilesa, the capital of Ijesa kingdom and one of the larger Yoruba towns, was founded in the early 16th century. The city is situated in between the larger regional centers of Oyo and Benin, round the upper ranges of the Osun, Sasa and Oni rivers. Ilesa is the metropolitan city of the Ijesa people. It is a classic example of a celebrated Yoruba town with a "crowned head"; it is ruled by a monarch bearing the title of Owa Obokun, Adimula of Ijesaland. Owa is the political and spiritual head of Ijesa kingdom.

Owa palace is quite big and located at the center of the city and the palace is set within its rectangular fifty-one acre ground, and is surrounded by a high mud-brick wall that turrets above all the buildings in the town. Within the palace wall resides the official and civil center of the kingdom, a place for noble empires and the most powerful shrines of the gods. Innovative symbols bloom in the palace: pillar posts in the form of horsy figures, kneeling figures, some genre in relief panels and there is an impression of such decoration, within the palace ground, that serves as perforated opening rather than an ordinary wall break. All these are contained in the architecture of most Yorùbá palaces ornamentation. In this study classified into two: old and new. The old afin (a heritage building) is the socio-cultural, official and political center of the Ijesa kingdom, while the new palace (current structure) serves as the welcome and abode of the present Owa Obokun, Oba Adebisi Aromolaran. 


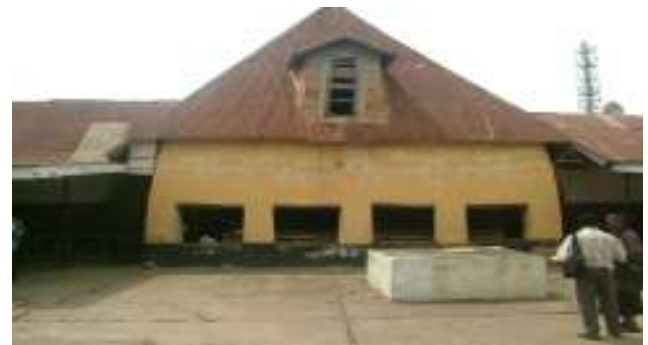

Figure1 showing turrets above the palace building

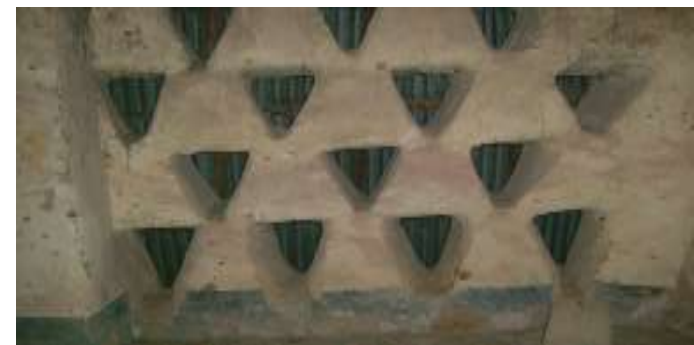

Figure 2 perforated openings as ornament in the palace

The new building is also the administrative center of the Owa's palace. Sculpture and edifice are two close objects that accentuate people's uniqueness and their cultural environment. The flair and style of Owa's palace and those titivating major roads and streets in Ilesa could therefore be said to reflect the socio-cultural expansion of Ilesa as a city-state and the vitality of the Ijesa people in general. Owa Atakunmosa, built Owa palace as a distinctive, colossal cultural ornamented building and the second largest (form and size) in that area. Although, now the state of the palace including the cultural objects raises alarm about how Ijesa people neglect this well adorned palace that is relevant to Yoruba palace ornamentation.

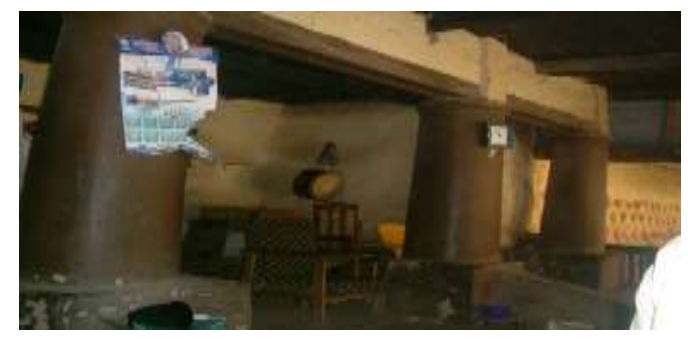

Figure 3 ornamented columns in palace courtyards

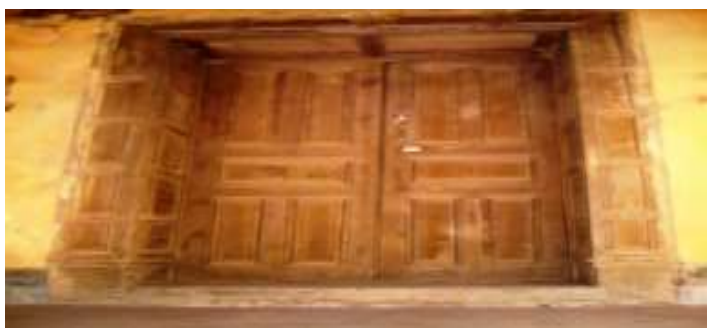

Figure4 picture of ornamented doors in the palace

\subsection{ALAKE PALACE IN EGBA-AKE}

The palace of the Aláké of Ėgbàland is possibly the smallest among the first class king's palaces, covering only about six acres in 1966 when it was surveyed. It is also one of the modest of the palaces when compared to Ọyọ́, Ilésà, or Ife examples. The size of the palace was said to have been determined by the manner in which the site was chosen. Oral tradition has it that the first Aláké was asked to throw stones twice, and that the distance to which he threw determined the extent of the palace. Much of what exists today have been renovated such that many courtyards and other traditional spaces have been converted to new uses. Alake of Egba's palace is rich in art, culture, history and the tradition of the Egba empire. All about the Alake's palace boastfully displays the superiority of the Egba people and it is worth exploring. At the entry of the palace is a gate flanked by two magnificent columns that have the king's emblem. There is a bar connecting the pillar which has the inscription: "Aafin Alake Ti Ile Egba," translated as "the palace of Alake of Egbaland." Egba-Ake people are known historically for being freedom-fighters, intelligent, artistic and agriculturalist Yoruba speaking people hailing from the southwestern part of Nigeria. They have since been concentrated in the vicinity of Abeokuta, the capital of Ogun State. The museum called Idiere where Alake in listening to various complaints from the community who sought for redress. Idiere contained twelve decorated columns (owon) and different sculpture were displayed there as ornaments and the wall of the museum was decorated with different autistics work depicting the vocation of the first Alake of Egba (Okekenu1) as sculptor.

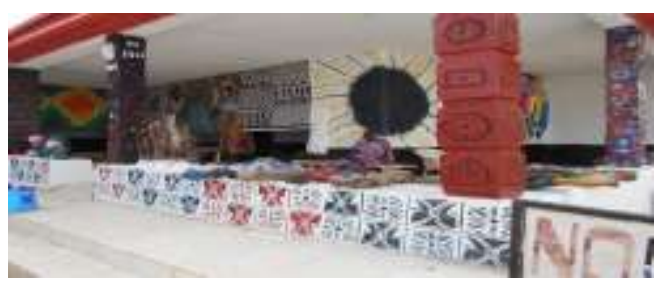

Figure5 Museum called Idiere in Alake's Palace 


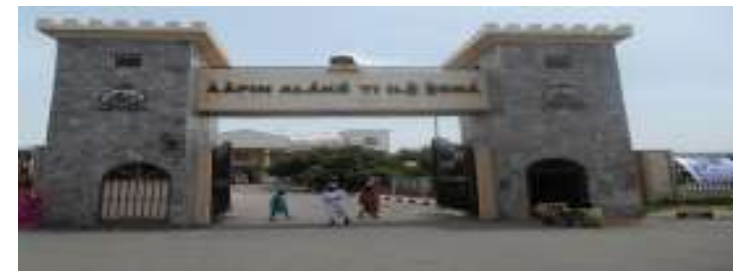

Figure6 Magnificent columns at the entrance of Alake's Palace

\subsection{CONCLUSION AND RECOMMENDATION}

This study has revealed importance of two Yoruba ways of beautifying palaces. Yoruba people have different ways of decorating their palaces that is peculiar to the unique cultural and traditional values of the town in question. Yoruba palace ornamentation comprises the traditions and values that define culture; it is both a structure of meaning and an enabler of the construction of meaning. In other words, ornamentation has a basic statement for which it was created (meaning); the mutual concerned and relevance of such artifact, form, or object gives it a name, root and status in addition to identity as material culture of the designing community. Yoruba artistic intellect was strongly proclaimed in the decorative enhancement of the built environment. The study asserted that aesthetics with regard to traditional palace ornamentation is not just about beauty and the philosophy behind it, but everything that contributes to Yoruba cultural meaning of autistics work in Yoruba palace structures. The varieties of ornamentation adopted on the palace fabrics are influence of a combination of culture and tradition of the community that the palace is located. The traditional arts should be revived (like it occurred in Renaissance period in Europe, characterized by the revival and sustenance of the Greco-Roman arts and ideals). The traditional arts like carving, bead-making, brass/bronze casting, etc., should be revived, and developed by infusing latest technology and encourage as occupation alternatives to business and white collar jobs. Such products should be utilized in the service of monarchs and advancement of Yoruba culture.

\section{REFERENCES}

1. Vlach, J. M. (1976). Affecting Architecture of the Yoruba, African Arts, 10 (1): 48-53, 99. Interviews.

2. Balogun, O. (1979). "Form and Expression in African Arts," in Introduction to African Culture: General Aspects, 69: Paris: UNESCO.

3. Denyer, S. (1979). Introduction to African traditional architecture: A historical and geographical perspective. London, England: Heinemann.

4. Dmochowski, Z. (1990). An Introduction to Nigerian Traditional Architecture, South-West and Central Nigeria. Lagos: National Commission for Museums and Monuments. Vol 2.

5. Akintoye, S. A. (1971). Revolution and power politics in Yoruba land 1840-1883: Ibadan expansion and the rise of Ekitiparapo (Ibadan History Series). London, England: Longman.

6. Fadipe, N. A. (1991). The sociology of the Yoruba. Ibadan, Nigeria. Ibadan University Press.

7. Akintoye, S. A. (2010). A history of the Yoruba people. Dakar, Senegal: Amalion.

8. Dmochowski, Z. R. (1987). An introduction of Nigerian traditional architecture: Southwest and Central Nigeria (Vol. 2).

9. Idowu, E. B. (1982). Olodumare [God in Yoruba belief]. Ikeja, Nigeria. Longman Nigeria.

10. Ojo, A. (1968). Traditional Yoruba Architecture. Journal of African Arts, (1)3. pp. 14- 17+70-72. UCLA James S. Coleman African Studies Center Stable. Accessed 12/07/2019

11. Krapf-Askari, E. (1969) Yoruba Towns and Cities: An Enquiry into the Nature of Urban Social Phenomena. Oxford. Oxford University Press, p.7.

12. Aderemi, A. (1966). Preface in G. J. O. Ojo,,s Yoruba Palaces: A Study of Afins of Yoruba Land. University of London Press Ltd.: London. London, England: Ethnographica. 